This item was submitted to Loughborough's Research Repository by the author.

Items in Figshare are protected by copyright, with all rights reserved, unless otherwise indicated.

\title{
Invoking a community of engagement: mobility and place in a small English town
}

PLEASE CITE THE PUBLISHED VERSION

http://www.ashgate.com/isbn/9781409401032

\section{PUBLISHER}

Ashgate $@$ Brigitte Bönisch-Brednich and Catherine Trundle

VERSION

AM (Accepted Manuscript)

\section{PUBLISHER STATEMENT}

This work is made available according to the conditions of the Creative Commons Attribution-NonCommercialNoDerivatives 4.0 International (CC BY-NC-ND 4.0) licence. Full details of this licence are available at: https://creativecommons.org/licenses/by-nc-nd/4.0/

\section{LICENCE}

CC BY-NC-ND 4.0

\section{REPOSITORY RECORD}

O'Reilly, Karen. 2019. "Invoking a Community of Engagement: Mobility and Place in a Small English Town". figshare. https://hdl.handle.net/2134/15696. 
O’Reilly, K. 2010 Invoking a Community of Engagement: Mobility and place in a small English Town. In Bönisch-Brednich, B and Trundle, C. eds, (ed) Local Lives. Migration and the Politics of Place, Farnham, pp.135-150

\section{Invoking a community of engagement: mobility and place in a small English town. Karen O’Reilly}

This chapter draws on ethnographic data from a small East Midlands town in England to demonstrate that local community is a resource for identity formation and expression, as well as collective claims for place-based material resources and emplaced social networks of daily relationality. Community is brought more into play in times of anxiety, such as when urban restructuring, flexible labour markets, globalising processes, and increased levels of migration impact on people's daily, lived experiences. The expression of community boundaries, however, is not (necessarily) drawn foremost along ethnic/foreigner/immigrant lines, but along the lines of mobility and instability. Migration, in the situation I describe, is thus feared not for the immigrants it brings but for the changes it promises, and especially the transience and loss of continuity. Disputes about the symbolic borders of the community often play out with regard to disputes over the real geographic and physical borders of the town, and disputes over the economic and political boundaries and the material resources these enable or disable. Emplaced memories and narratives of the past are central tools through which people recreate community identity and belonging in public spaces on a daily basis and effectively encourage locals (of all backgrounds) to collectively fight for or defend resources. Overwhelmingly these narratives deploy notions of both victimhood and a community of engagement as a counter to the threat of transience.

\section{Real lives}

Mrs Walton is 85 years old. Her husband, who died ten years ago, was the general practitioner in Shepshed for thirty years. She was introduced to me as the doctor's wife. Mrs Walton lives alone in a big house with five bedrooms; her sons have moved away to London and Birmingham. Although she has dementia she manages to live alone because she has a gardener and a cleaner who call in regularly, and most days she walks across the road to the chemist or the post office or drives to the co-op down the road. She also eats out five days a week, in a pub in the next town, with some friends. She never eats at home because, she says, 'I'm never hungry so I forget to eat, but when I go out I feel like eating'. Mrs Walton's sons worry about her but she refuses to be moved out of her home until (in her own words) she is carried out in a coffin.

Jim is 35 years old. He used to work as an electrical engineer but in his spare time he enjoyed driving his Kawasaki motorbike on long trips around the UK with his wife on the back. But one day a car driver stopped suddenly in front of him and Jim crashed into the back of it, smashing his skull and ribs and breaking his neck. Jim is no longer able to care for himself and now lives in supported housing in Shepshed, a hundred miles from his home town, and is not permitted to see his sons because he finds it difficult to control his temper: 'I don't mean it, but I just get angry sometimes and I shout and stuff'.

Tom lost his sight when he was 11 years old. At 26 he still lives with his family in Shepshed and is very happy there. Once a week he makes his way down to the community centre, 'I walk there all by myself' he told me proudly, to meet with other blind and partially sighted friends. They make things together, drink coffee and tea, and share stories. Tom makes furniture for doll's houses - tiny tables, chairs and lamps - which he sells to raise money for the community centre.

Tracy is a mother of two young children. She has lived in Shepshed all her life; her mother, father, grandmother and two aunts also live in Shepshed, as do Tracy's sisters and brother. Tracy's husband, 
Glen, works in the nearby town of Loughborough. It is only ten miles away but Tracy told me she wished he could find work in Shepshed. Tracy never wants to leave her home town. 'I love it here. I know everyone and everyone knows me'. She has been as far as London once, but she didn't really like it. 'Nottingham is enough of an adventure', she said.

These were some of the many people I met when I began my study of migration in Shepshed. They are illustrative of the arguments I elaborate below - that place-based, material resources, face-toface communities, localised identities and a sense of shared history and commitment to a geographical place are especially important for some groups of people, especially those who lack mobility or its desire.

\section{Shepshed}

Shepshed is a small East Midlands town, with a population of approximately 14,000 , centrally located in a region that has experienced dramatic changes in recent decades as a result of immigration from various parts of the globe. Shepshed is 30 miles from Leicester, a large city of 285,000 people and forecast to be the first city in the UK with a majority non-white population. Leicester has a very large south Asian community, which settled for the main part during the 1970's and 1980's. But migration has been an important feature in the region more widely with, in the past few years, Shepshed and nearby towns experiencing a notable migration of Polish and other Eastern European migrants looking for work in agriculture and industry. Nevertheless Shepshed remains predominantly white (98\% in the 2001 census) with some small visible presence of an historical migration in the shops and restaurants owned and run by ethnic minorities and in the businesses around the edge of the town that employ people of a range of backgrounds. The town is mentioned in the Domesday Book but grew especially as a centre for the wool trade during the $17^{\text {th }}$ century, and as a result of factory production of hosiery in the $20^{\text {th }}$ century. Now, however, since the construction of the M1 motorway in the 1960's and the closure of all the factories in the past $20-30$ years, it has become known as a dormitory town (a town where people live but don't work) for Loughborough, Leicester and Nottingham. (This label is used overtly on the town and borough council web sites as well as the web site of the Member of Parliament for Loughborough, Andy Reid).

There is a very strong, thriving community in Shepshed. There are primary schools, a high school and community college, two bustling cafes, community centres where a range of societies and groups regularly meet, a thriving library, a (small) Friday market, two post-offices, and several small shops of various kinds including a butcher and baker. People are to be seen walking about the town, especially on market day. Kim's Cafe is a crucial institution, a central meeting place for teenagers, people with learning difficulties, young mums and children, working people popping in for a sandwich, older people taking advantage of special deals, and just about everybody else. The chemist in Charnwood Road knows most of his customers (and their ailments and medicines) by sight. In the post office one can overhear neighbours catching up with the latest gossip, families finding out about loved ones they haven't seen in a few days, lonely people sharing a few words with anyone who will listen, young people making arrangements for their social lives. Many people told me how much they love the town, describing the neighbourliness, the good facilities, the range of social clubs, and the sense of community. Nevertheless, at the very outset of my ongoing ethnographic study in Shepshed, looking to examine the impacts of migration on a small town, I was overwhelmed with stories of loss. For many Shepshed people (of all ethnicities) the label 'dormitory town' implies migration, rapid change, transience, and lack of stability and continuity. But here people are not talking about international but internal migration. For them, migration has little to do with race, or ethnicity, and has everything to do with community, place, locality, and commitment. Surprisingly, in response to my questions about migration to the area, people spoke of their fears that Shepshed is changing, dying, losing its heart (or its core); they especially discuss the loss of 
material and emotional resources for those who have commitment to, and need, Shepshed as a place.

Shepshed is changing; it is dying. We are becoming nothing more than a dormitory town. There is nothing here for locals, no jobs, no shops, it's all going to Loughborough (a nearby town with a population of 50,000 ) (Glen, care worker)

We are not really aware of the more recent migrations since these people work in the factories near here but tend not to live in the town (Shirley, library worker)

... Shepshed changed and it's like you see it now, it's totally soulless, there's no real heart, no civic, there's nothing.. . The knitting industry sort of drizzled away, but before that things started to change because the motorway came, and I've talked to people who only came to live in Shepshed because it was a good place to get to other places! (Edith, retired)

For many people living in Shepshed the relationship between migration and community is simple: too much mobility is leading to a loss of community.

\section{The sociology of mobility and materiality}

Globalisation and increased levels of mobility - of things, ideas, people, and capital - have led to a growing concern on the part of social theorists and empirical researchers alike with flows, fluidity, transience and change rather than structures, communities, cultures, and peoples (Bauman 2000, 2005, 2007, Urry 2000). There has been an increased emphasis on movement rather than borders, on spaces rather than places. Globalisation, in this rendering, challenges territory, place, nation and state; it threatens borders and controls, and turns its gaze, positively, towards the virtual, the mobile and the communicative (Castells 2001). But, perversely, it seems the constant movement, individualism, competitiveness, increased insecurities, rapid pace of change, anxieties, and fragmentation engendered by the postmodern condition lead humans to revive, with an increased sense of urgency, what is essentially a timeless search for community. 'One of the unintended consequences of modern capitalism' as Bauman notes 'is that it has strengthened the value of place, arousing a longing for community' (1998: 138, my emphasis). In the face of detachment people yearn for the sharing, the cosiness, warmth and comfort that community promises (Bauman 2001). But, for Bauman, this search is unfortunately doomed to failure because community demands responsibilities and commitment, which are now rejected as antithetical to individual freedom. This is the paradox of our times.

Apparently, we need not fear that community is gone forever. Contemporary mobile life, postmodern theorists contend, is not bereft of community; the sense of belonging and security it provides can now be found in the form of highly individualised communities, based on diverse means of communication (Delanty 2003). Communities are no longer (only) located in places or cultures, but need to be traced in the form of networks, communication flows, and virtual ties centred around individuals (Castells 2001); they are to be found in ways of expressing a sense of belonging rather than in firm structures, places or spaces; and they are fluid, open, and changeable. However, such virtual or 'personal communities' (Wellman 1999, Spencer and Pahl 2006), though often portrayed as liberating, are themselves fleeting, transient, insecure, and 'unable to resist the forces of globalisation' (Delanty 2003: 195). They do not satisfy the desire for communities of place. 'The revival of community today is undoubtedly connected with the crisis of belonging in its relation to place' (Delanty 2003:195, my emphasis). As David Harvey (1990) contends, such postmodernist renderings of community merely overlook the reality on the ground for many urban dwellers (a reality of poverty, helplessness, fragmentation and marginalisation) and encourages us all to accept the disintegration or separation of community and environment. It is conditions such as economic 
recession, loss of industry, migration (including internal migration from rural to urban spaces, and later vice versa), and neoliberalism that give rise to a need to revive or sustain communities. The study of diverse mobilities that transcend local, regional and national borders (Urry 2007), denies or overlooks the relevance of place. For the people in my research, community is not simply symbolic (Cohen 1985) or imagined (Anderson 1983); it does not exist sufficiently in the space of networks and flows, and cannot be decoupled from daily interaction (Amit 2002; see Phillipson and Thompson 2008).

Phillipson and Thompson (2008) suggest that there is little articulated sense of community among working class people; they believe it is much more likely that middle class people will express an 'elective belonging'. Yet here, where the community's resources are under threat, it is the working classes, the poor, and the powerless who feel threatened by an influx of middle class commuters, by the control of a middle class borough council, by transience, change and loss. Here a sense of belonging is invoked that is tied to a commitment, over time, to local and family history. So, rather than the 'elective belonging' of the middle classes there is a belonging based on investment, an engaged belonging which deems itself worthy as a result of history, time, locality, work, family, and commitment. This is therefore a community opposed to mobility and movement, transience and change, since these do not allow for such investment and engagement. Without investment there is the threat that the community will die. However, most interestingly, some ethnic minority groups and some recent newcomers are able to claim membership of the community as a result of expressions or acts of investment (of time, effort, concern) and so the community is not opposed to ethnic minorities so much as to mobility and transience. As Vered Amit (2002) suggests, community is first and foremost a claim of, or for, social engagement.

\section{Material culture}

People render their communities real to outsiders (and participant observers) through the stories they tell and through the public face they reveal via events, actions, leaflets, books, and photographs. Certain events, discussions and interviews in my research are notable for the centrality of material factors; locals frame their belonging in terms of the loss or struggles over parks, buildings, shops, markets, banks, housing estates, the swimming pool, the volunteer service, the housing estate, and the motorway. Kathy Burrell (2008: 64) found the same in some of her interviews with Polish migrants. This is not surprising, she says, others have noted 'the emotional connection between people and things' (see Miller 2005). In Shepshed, certain events and places have become synonymous with, or symbolic of, continuities and others of change; certain things are imbued with memory, others represent loss. Interviews highlight how people's economic and cultural experiences are specific to material contexts, and for them to move away (or to lose) the material, physical context implies losing one's past experiences and one's security. As Morton (2007: 158) has suggested, the interweaving of stories of the community with memories of the past and fears about the future built environment are 'suggestive of a deeper relationship between dwelling and social life'. The built environment clearly influences the way people think about and perceive their world, but more than that the material provides or denies real resources needed by people in their daily lives. Morton talks of 'memory work as a social process related to the house' (2007: 160). He investigates the ways in which 'the material home may structure and influence the reproduction of embodied forms of memory'. If, what we build in the future is a way of collectively (re)constructing a memory of how things were in the past, then having no control over this is anxiety-ridden and threatens that we lose our memory of who we were as well as actually losing our community and its resources in the future.

\section{The material loss of community}

Overwhelmingly, what is being expressed in Shepshed is a fear for the loss of resources sufficient to sustain an emplaced community in the future. Community is thus expressed in terms of place-based 
material resources, such as shops, jobs, and housing; and it is claimed within an emplaced, embodied and intricately networked being and belonging. I have been told numerous stories of resources that are already lost or under threat of closure, and of goods and services that are no longer locally available. A major, overtly expressed, anxiety was with the number of shops that are closing down. This is a more pressing fear in the current economic climate but is not a new concern. If there are too few shops, it is feared, few locals will spend time in the town at the weekends or during the daytime. This will leave the place empty, with no real heart or centre, leading to increased crime and run-down areas. This is not a baseless fear: shops in the town were already closing before the recent recession and at a last count 9 shops and businesses in the town centre were shut and 4 were boarded up. The town centre looks scruffy in some parts and deserted in others. During one walk into town on a Friday (market day in Shepshed), I got talking to an elderly man who told me, as we walked along the road side by side, that his wife had died a couple of weeks ago, just before their $52^{\text {nd }}$ wedding anniversary. He was clearly distraught and looking for anyone to talk to about his loneliness. I had seen him leave the tattooist as I walked past and have a quick chat with another woman before crossing the road to me. He told me he was dreading going home to his empty house, and then he said: 'but Shepshed isn't like it used to be. You don't see people you know walking about like you used to, because there are hardly any shops left now'. Shops are thus representative of a sense of locality, a place-based material and active, embodied belonging to the town. Without shops there is less reason to be and to spend time in the town.

The loss of local jobs too, is shown to represent a loss of emplaced community. As Manuel Castells (2001) notes, local communities are not so much undermined because of mobility (which he believes has been exaggerated) but because of the changing nature of work. It was indeed work that kept people in contact within their villages and towns and formed the basis of their interaction, not just its existence but the rhythm of work and the regularised pattern of a working week. As Edith, a retired woman who has lived in Shepshed all her life, told me in an interview:

We used to have loads of shops, and when the factories closed on a Friday night all the ladies would rush out with their pay packets - I've got me money - and the town buzzed, absolutely buzzed, because you went and got your groceries, you went and got your meat, you paid your papers, and everybody was there rushing around... As the factories closed so did the shops start to close.

People worry about the lack of jobs in the area because this takes people out of the town every day to find work elsewhere and thus undermines the intricate networks of emplaced relationality on which their daily lies were based. But a lack of local jobs can also lead to high rates of unemployment if enough local people are not able to compete in the wider labour market, and people are justifiably worried about the social ills that high unemployment can mean for an area. Again, these fears are not ungrounded. In many interviews and conversations locals recalled Shepshed's past as a centre for hosiery; the prior vibrancy of the town has been described to me at length and its employment history is celebrated in a range of publications about the town. But this social history is now a story of loss, of closure, and of rapid change.

In the 27 years I've lived here I've seen a lot of changes, ever such a lot. Oh yes. There's been lots come to live here for work first, but now they live here to go elsewhere (Carolyn, office worker, field notes)

Shepshed has changed out of all recognition, it was very much a village, people knew each other...It always had a lot of hosiery factories, well the hosiery industry began in people's own homes and didn't go into factories until later on, and these were very small factories. 
...People worked in hosiery all their lives, the men worked the machines, and there was a great tradition of outwork - the women working in their own homes doing mending and linking, and framework knitting was sometimes done where people had their homes adapted to fit these machines in. (Freda, retired)

Locals also worry that there will not be enough reasonably-priced housing for their children to buy when they grow up. Children will thus be forced to move away, whether they wish to or not, which in turn will mean locals do not see so much of their children and grandchildren, are compelled to travel more often themselves, and have no one left to look after them as they age. This is contradicted by the argument that there is too much cheap housing, which runs its own risks of attracting, as Bernard, a retired man told me, the 'wrong sort of person to the town. I mean we all know that people who get cheap homes don't invest so much in looking after them, don't we?'

Behind these key concerns about jobs, housing and shops, is a sense the town is changing against people's will; and the tales of loss can be supported with material evidence. The town still has two post offices, but only because locals held a fierce campaign to fight closures. There is a very busy volunteer centre, but the organization that runs it has now merged three small units into one with the result that the town's local office is only open in the mornings and will probably close altogether in the near future. There are only two ATM machines in the town now, and the only bank recently closed despite a protest against its closure. There has been a campaign to improve and maintain the public toilets in the town but these remain a disgrace while Loughborough's public toilets have won awards. There used to be a Christmas parade with a Santa on a sleigh, but this has been cancelled because of difficulties of gaining adequate insurance against risk. There is an ongoing campaign not to have the M1 motorway (which runs past Shepshed between the town and Loughborough) widened to three lanes. There is no longer a carnival because the organization that ran it has folded. There was a community college running a wide range of adult education classes but this has closed down. Expressing his own concerns about the undermining of place-based communities, a pharmacist told me:

The government is allowing chemists to merge into bigger and bigger concerns where customers are no more than a number - no one knows anyone any more. It used to be that my job involved talking to people and giving a personal service. I know the doctors at the surgery, they can ring me if they have a question about someone's medication and I can ring them (Sam, field notes).

There is an overwhelming feeling that the ongoing loss of both material resources and of local, face to face networked relationality is occurring against the will of those it affects most, leading to a sense of both struggle and defeat.

\section{Loss of control over their own fate}

Shepshed town is part of Charnwood Borough, in the County of Leicestershire. It is very difficult to work out which council (town, borough or county) has control over which resources. But Loughborough, a town with a population of approximately 50,000 and very close to Shepshed geographically (separated only in material terms by the M1 motorway and the Garendon Estate) is clearly seen as a threat to Shepshed's identity and political and economic autonomy. A key difficulty is that Loughborough is the largest town in the borough, with a third of the borough's population. Although still relatively large, Shepshed is small in comparison and therefore has to compete for town resources. Many Shepshed locals would like their town still to be a village and often use that term when describing it. The greatest fear they have is that it will be merged, physically and symbolically, with Loughborough as part of the neoliberal restructuring affecting small towns across the country. While they demand the resources that a town of its size needs, they feel that most 
resources go to Loughborough as the bigger of the two towns. Other villages in the borough have managed to retain their identity as villages, as rural and middle class. Shepshed has an industrial past, is more working class, and locals express a feeling of having lost control over its future. At a council meeting, for example, one of the councilors was grumbling that they had written to the borough council (based in Loughborough) about the naming of a street and no one had replied to her letters. 'They just ignore us. We cannot get a response' she said (field notes). Another councilor told me:

Since the urban district councils joined with the others in Charnwood Borough they feel it is all about Loughborough. The trouble is many of the councillors don't live in Loughborough but it feels as if it's all they care about. There are 150,000 people in Charnwood and over 100,000 do not live in Loughborough, yet all our taxes are spent improving Loughborough (anonymous, field notes)

Loughborough also represents a threat to the town because, as a result of urban restructuring and economic and political centralisation, it has the material resources that attract people from Shepshed for shopping, using a bank, eating out, and social activities.

Until a few years ago Shepshed was a village and it was self-contained. We had all the shops we needed and we didn't have to go into Loughborough. Now some people blame Loughborough for what they have lost, their community college, their shops. The community college used to have all sorts of evening classes but now there isn't enough money, these things are no longer funded locally, and there is so much emphasis on learning and improvement nowadays. (Fred, volunteer worker, field notes)

Even a study undertaken to try to understand Shepshed's needs for the future was organised by the borough rather than the local town council, and 'totally missed the point' (Bruce, town councillor) and 'was a waste of time and money' (Mary, library worker). The sense of powerlessness and frustration pervades many stories. Shepshed people believe they are seen as lower class, or as poorer, or rougher. It was described to me as a 'dumping ground', with lots of care homes, social housing, and temporary homes for those waiting to be permanently housed, rather than the facilities they really need.

They dump their baddies here, from Sileby across to Loughborough, they dump them in those council-owned flats, they dump the druggies and everything (Carolyn, office worker)

Loughborough always treats us as if we are a bit common. Woolly backs, that's what they used to call us. It's always been looked down on, it's always been a bit scruffy, a bit downmarket. (Edith, retired)

The people who express a fear that Shepshed is losing its heart, or is dying, are people who need local material and emotional resources, be it friendship, employment, a home, shops, a bank, a social or community centre, local services, familiarity, a church, a council with its own resources, or somewhere their children can live when they grow up. Men and women working as volunteers in the town, councillors of all political parties, a vicar, a schoolboy, a newsagent, a chemist, a doctor, a schoolteacher, along with many others, started our conversations with phrases like: 'No one seems to care about Shepshed any more' (Denise, a town councillor); 'Shepshed has died in recent years' (Ruth, retired), 'Changes have been made to the detriment of Shepshed itself by outside sources' (George, a town councillor), 'It needs a heart, a core' (Julie, full time mother), 'it used to be that people grew up and stayed here, but they can't now. It's just a dormitory town, no work' (Dan, barman). Some people, especially those outlined at the start of this paper, really need these 
resources locally. Others simply have an identity as Shepshed folk and want to enjoy a local identity and be part of local networks.

\section{The threat of migration, or mobility}

The fears and concerns expressed above are often framed in terms of lack of commitment to, or investment in, the town; community is thus something within which resources and identity are mutually constituted. People particularly worry that too many of those who live in the town simply use it to sleep in, working and shopping and socializing elsewhere. In other words they worry about a lack of emotional investment as well as physical presence. The phrase 'Shepshed is just a dormitory town' (Brenda, care worker) is a negative denigration of mobility, not a celebration. In their important new book about the social cost of inequalities, Spirit Level, Richard Wilkinson and Kate Pickett (2009) observed that when people do not see each other on a day to day basis, when there is little face to face contact in the community, there is decreased trust, which in turn leads eventually to ill health. Again material factors are brought into play. The housing estates that have been built more recently on the edge of the town provide accommodation for outsiders (migrants from other parts of the UK in most cases). The M1 motorway, though it has some positive symbolic function in separating Shepshed from Loughborough, makes it easier for people to live in the town and work elsewhere. The migration that is feared is the movement into the town of people who constantly move out of it, every day for work, at weekends for shopping, or permanently at some point in the future. Barbara, a full time mother, described to me the tremendous changes she had seen just in her 27 years in the town, with the growth in numbers of residents working in the factories, the factories closing down, and then a new influx of people moving to the housing estates.

But, a lot of people move here because of the motorway. It's known as a dormitory town, ..it's been proven that a lot of people on that new estate (pointing) don't come into the town at all. They don't even know there's a co-op.

And others grumbled:

Shepshed went wrong somewhere. It had the potential to be a nice little market town..I think the problem is that a lot of people live in Shepshed but they don't shop here. They drive out of Shepshed. We're a dormitory town really. People always move on, move out, that's the trouble. (Ruth, retired)

There are too many new people now, like students, who just stay a while and then move on (woman on market stall, field notes)

Students, too, are seen as part of the dormitory phenomenon. Like ethnic groups in the past, they are treated as the dangerous outsiders, bringing crime, unsociability, lack of commitment to the town, and transience. These, and the dormitory residents, are the immigrants that Shepshed fears. People in Shepshed, interestingly, do not seem to fear migrants so much as their migration. There is some evidence that the British National Party (BNP) is attracting more support than previously, but most people I spoke to were more concerned about the rise of the BNP than they were about immigrants themselves. Shepshed folk worry that mobility, rather than immigration, will lead to a loss of identity for the town, to fewer people to care about it as a locality, to fight to maintain it in the face of other changes.

\section{Celebrating an engaged community}

Community identity is a way of talking about 'us' and 'us' is a collectivity that can help fight for resources. In Shepshed this collectivity, the community that is expressed or invoked, includes Asian shopkeepers, an Afro-Caribbean minister, a vicar originally from Singapore, a Greek family, as well as 
Shepshed folk 'born and bred' (people who have not only spent their whole lives in the town but can claim a relationship going back generations). As June, a volunteer worker, told me, 'Shepshed has a strong sense of community, and ethnic minorities are now part of that community'. Community is expressed here in terms of history and commitment; it is an engaged community. Anyone who can invest or has invested time and energy to the community is worthy of being a community member.

Community membership is invoked most strongly through historical ties. People are considered, or see themselves, as members of the community because they can talk about the past, how long they have lived in the town, and their families, thus demonstrating not only identity but also a temporal and emotional investment in community. People therefore talk about their past working lives in the town, or describe their family histories; they invoke memories of how things were, as seen in many quotes above, articulating an identity with place and locality. Others claim membership through virtue of the fact they not only live in Shepshed, but shop there, use the chemist, the supermarket, and (importantly) do not rely much on the things Loughborough offers. Others talk about their community involvement, their voluntary work, or council membership, the community groups they belong to, the campaigns they have joined, and so on. People also invoke community by telling me of others in the town I should talk to: Hilda who is 96 and lived here many years; the Asian chemist who knows everyone; the Indian man who owns the hardware shop and can get anything you need; the Greek family that owns several small shops in 'the parade'; Dr Singh, the general practitioner who has worked there for 30 years; the liberal councilor who has made it her mission to get a second supermarket in the town; the teacher at the community college who 'doesn't even live in the town but does a lot for it'. In all these invocations it is time, history, commitment, investment, and engagement that matter; in other words the opposite of all the things that mobility calls to mind.

Many of the themes discussed above are illustrated in the ongoing campaign not to allow plans to go ahead to build 3,500 new homes on a piece of land between Shepshed and Loughborough known as Garendon estate. Garendon is the estate of a very large, old house that was burned down in the late 1950s. The owner of the estate, the Squire of Garendon, also owns much of the land in Shepshed. Garendon Park, part of the estate, is protected as a national heritage site; under these plans the park will remain intact but surrounded by urban dwellings. Garendon Park and estate hold important symbolism and materiality for Shepshed people. The estate is used for walking and cycling and has a path running through it that links the town to Loughborough; but it also symbolises the separation of the two towns. It is also part of Shepshed's social history, as Edith told me, 'There's a bit of a folk memory of when Garendon was the big house, and your parents and grandparents worked there, and it was very important to some families'.

In protest to the plans, the Garendon Park Countryside Protection Group (GPCPG) has its own newsletter and a dedicated web site. A series of meetings have been arranged (by both the council and the protestors) to which local people have been invited to discuss the plans. Over 100 locals turned up at the Town Hall when the Borough Council attempted to justify Garendon as its preferred for location for the development. Shepshed people were clearly not happy with the plans. They objected that the development would render their town indistinguishable from Loughborough, except for the M1 motorway; they want to be separated by green space not a motorway. They grumbled that the development would not be of any benefit for Shepshed, since the inhabitants of the new homes will work and play elsewhere. Concerns were raised that Shepshed and Loughborough would simply merge into a huge urban area without any extra services or jobs. Some protested about the extension of what already amounted to their treatment as no more than a dormitory town; others felt the area would become even more run down and abandoned. It became very clear what people were fighting to retain: their own 'village' identity, local facilities, a green surrounding area, local jobs, and low crime. Sue, a teacher, told me of Garendon estate: 
It's the green wedge between us and Loughborough and we don't want that lot here do we? ...It's creeping closer all the time. There was a time when we were very separate. In fact a lot of people were worried about the M1 coming this way but in fact it stopped a lot of people coming to Shepshed, it's a bit like a motor between us and them. We don't want to be built up, we want it open and green... Eventually if we are not very careful I think perhaps eventually we are going to be tagged on to the end of Loughborough, and then we'll be the dog-end of everything won't we?'

The debate about the development of Garendon park estate serves as a reminder of the town's history. It acts as a reclaiming of that piece of land as Shepshed's, a collective remembering of a shared history, as well as an opportunity to express a unified identity. The resistance mirrors the defense of their locality against the wider world, against change, and, above all, against mobility and transience. The event at the Town Hall was thus a ritual expressing a symbolic boundary between Loughborough and Shepshed, which served to 'heighten people's awareness of and sensitivity to their community' (Cohen 1985:50); the kind of ritual which is often to be witnessed when the geosocial boundaries of a community are undermined or threatened.

\section{Conclusion}

Shepshed is a small town that has experienced rapid and drastic social change in the past few decades. Factories have closed down and locals now have to travel beyond their local community for work, shops and pubs have closed, younger people are moving out for work elsewhere, and little is left of what was once a thriving hub. Meanwhile, a motorway now passes so close to the town that it is possible to travel to nearby cities in short periods of time, and housing estates have been built to attract newcomers (migrants) who have no commitment to, and little time to spend in, their local community. Those who are left behind, those who need a local community for the material resources as well as the company it provides, have real fears that those things which represent community, security, locality, and constancy are being eroded at a pace of change over which they have no control. They can see their town becoming no more than a neglected part of the urban sprawl, tagged onto a larger town as an after-thought, a dormitory town where residents spend their nights each in their own home, to depart each day in a constant process of dwelling and travelling. In response to these fears, local people in Shepshed are not expressing fears about ethnic minorities or immigrants; what they fear is mobility itself. What they celebrate, then, is an engaged community an inclusiveness based on time, history, commitment, and investment - because only those who engage with their communities are prepared to fight for them.

It seems the constant movement, individualism, competitiveness, increased insecurities, rapid pace of change, anxieties, and fragmentation engendered by the postmodern condition lead humans to revive, with an increased sense of urgency, what is essentially a timeless search for community. And the virtual or communication-based personal communities of mobile individuals cannot satisfy the need for place-based, local, face to face contact, for some groups especially. The newly mobile world in which we live seems to have no place for the immobile, those for whom movement is difficult because of physical or financial limitations, or those who have insufficient resources with which to join the network society. As a result mobility itself is feared and we see a revival of 'engaged communities' invoking history, commitment, time and, perhaps, stasis.

\section{References}

Amit, V. (2002) Realizing Community: Concepts, Social Relationships and Sentiments. London: Routledge 
Anderson, B. (1983) Imagined Communities: Reflections on the Origins and Spread of Nationalism. London: Verso

Andy Reid, Member of Parliament for Loughborough Constituency, Shepshed Page, www.andyreedmp.org.uk/shepshed.html (26 September 2009)

Bauman, Z. (1998), Globalization: The Human Consequences. (Cambridge: Polity).

— (2000), Liquid Modernity. (Cambridge: Polity).

— (2001), Community. (Cambridge: Polity).

— (2005), Liquid Life. (Cambridge: Polity).

— (2007), Liquid Times. Living in an Age of Uncertainty, (Cambridge: Polity)

Burrell, K. (2008). Managing, Learning and Sending. The material lives and journeys of Polish women in Britain. Journal of Material Culture, 13(1): 63-83

Castells, M. (2001). The Internet Galaxy, Reflections on the Internet, Business and Society. Oxford University Press: Oxford

Cohen, A. (1985). The Symbolic Construction of Community, London: Routledge

Crow, G. (2008) 'Recent rural community studies'. International Journal of Social Research Methodology, 11(2): 131-139

Delanty, G. (2003) Community. London: Routledge

Harvey, D. (1990) The Condition of Postmodernity: An Inquiry into the Conditions of Social Change. Oxford: Blackwell

Miller, D. (Ed) (2005) Materiality (Politics, History and Culture). Durham: Duke University Press.

Morton, C. (2007) Remembering the House: Memory and Materiality in Northern Botswana, Journal of Material Culture, 12(2): 157-179

Phillipson, C. and Thompson, P. (2008) 'Whither Community Studies? A special issue on researching community studies, past and present'. International Journal of Social Research Methodology, 11(2): 87-91

Spencer, L. and Pahl, R. (2006). Rethinking Friendship: Hidden Solidarities Today. New Jersey: Princeton

Wellman, B. (1999). 'The Network Community', in B. Wellman (ed). Networks in the Global Village: Life in Contemporary Communities. Boulder, CO: Westview, 1-48

Wilkinson, R. and Pickett, K. (2009) The Spirit Level: Why more equal societies almost always do better, Allen Lane.

Urry, J. (2000) Sociology Beyond Societies. Mobilities for the Twenty-First Century. London: Routledge 
Urry, J. (2007) Mobilities. Cambridge: Polity

Freda described to me in great detail where I could see the material traces, the evidence, of this past: machines I could go and see in local museums, evidence of changes in house construction. Her stories would take me to the area via many place names that were locally understood but which had to be explained to me, demonstrating in the process her historically embodied location in the area and its community. For example,

If you go up the top of the knob. No I can't say that can I? (laughs) You go up Kirk Hill, you know? And there's a garage, and a little island at the top, and we used to call that the top of the knob. So, you go there, where Leicester Road starts and if you stand on the junction and look slightly over to the right, there's a big tall house, and that's where one of the hosiers lived. 